\title{
DIONÍSIO, UMA BIOGRAFIA
}

Felipe Luiz Gomes Figueira ${ }^{1}$

eu me escondi inteiro nos meus poemas

para poder exibir a vocês os meus pedaços

Sossélla

Sinto-me como um viajante que vive dia-a-dia os segundos do presente, como uma águia incapaz de mover guerras num horizonte que se põe...

(minha ampulheta exauriu-se)

Trilhei inúmeras dobras até retornar em angústias não superadas.

Um fantasma sempre usa máscaras para poder voltar de maneiras diferentes.

(minha ampulheta exauriu-se)

${ }^{1}$ Docente do IFPR (Campus Paranavaî) e do Colégio Nobel. Mestre em Educação pela Universidade Estadual de Londrina (UEL) e Doutorando em Educação pela UNESP. 
Os verbos mais hostis foram vividos em catedrais abandonadas, em asilos esquecidos, em "rotas alteradas".

Eu sonho

Tu forjas

Ela mata

(minha ampulheta exauriu-se)

Permaneci firme em minhas decisões,

por mais duras que fossem.

Olhei pacientemente as poeirinhas se perdendo

e, ainda assim, permaneci poeta.

(minha ampulheta exauriu-se)

Minhas raízes tinham certeza dos meus objetivos.

Amar foi uma conseqüência da minha coragem e de alguns delírios que eu semeava.

(minha ampulheta exauriu-se) 
Escrevi minha ampulheta com versos em preto e branco, gota a gota trágicos.

Todos os dias caminhei sobre mim mesmo: na solidão, em companhia e no tédio.

(minha ampulheta exauriu-se)

Naqueles caminhos relembrados virei minha ampulheta-testemunha em forma de aurora eclipsada. (minha ampulheta exauriu-se)

É no labirinto chamado vida que minha memória se tornou esquecimento em sua vida. (minha ampulheta exauriu-se) 
Em um mês vivi

"a musa" e "a cortesã " num só tempo dividido em dois: o antes sob um túmulo, o agora sobre uma ópera. O sabor do efêmero ficou...

(minha ampulheta exauriu-se)

Girei minha tragédia e ela se virou contra si mesma.

(minha ampulheta exauriu-se)

Talvez, no teatro da vida, cada segundo olha o velho sob seus olhos, a (biblio)grafia dos oceanos, o novo sobre a aurora.

(minha ampulheta exauriu-se) 
Calei-me

antes que a caça me caçasse num beco sem saída onde sou sempre o último.

(minha ampulheta exauriu-se)

Conheci

o naufrágio em segundos.

Por pouco caí no abismo da minha luta contra monstros que não se foram.

(minha ampulheta exauriu-se)

Não me iluminei com os milhares de vaga-lumes que me saudavam noite e dia. "¿haverá um momento em nunca?” A ponte não me encontrou... (minha ampulheta exauriu-se) 
Caí

nas sombras de sonhos ausentes, anômalos, suicidas, inconquistáveis, miseráveis.

(minha ampulheta exauriu-se)

Bani

do meu vocabulário:

malmequer, mal olhado, mal-estar.

(minha ampulheta exauriu-se)

Minha biografia não se encontra presa à falta de experiências, à falta de tropeços, a lamentar-se sobre si mesma: no absurdo da tragédia, no abismo da comédia,

(minha ampulheta exauriu-se) 
Em minha cítara

conciliei os ímpetos mais irracionais que a vontade poderia me exigir. Aqui fala um vitorioso amigo de Sileno. Sou Dionísio... um observador. (minha ampulheta exauriu-se)

Sinto-me venerado pela existência num mundo que sempre me reconduz a uma síntese de acasos e destinos, a ser um nômade entre os nômades, um vivo entre os vivos: a isto chamo de essência.

(minha ampulheta exauriu-se)

Entre o sol e a lua permaneceu um muro entre as flores e as histórias de minha memória. 
Meu destino é muito grande, meus objetivos muito restritos. Quando olho minha ampulheta é impossível controlar os soluços... 